\title{
Senescence and Abiotic Stress Induce Expression of Autophagy-related Genes in Petunia
}

\author{
Juan O. Quijia Pillajo, Laura J. Chapin, and Michelle L. Jones ${ }^{1}$ \\ Department of Horticulture and Crop Science, The Ohio State University, Ohio Agricultural Research \\ and Development Center (OARDC), 1680 Madison Avenue, Wooster, OH 44691
}

\begin{abstract}
AdDitional INDEX words. autophagy, $A T G$ genes, chronic and acute salt stress, flower senescence, ethylene, low fertility, nitrogen deficiency, phosphorus deficiency

ABstract. Autophagy allows for the degradation and recycling of macromolecules and organelles. It plays a significant role in cellular homeostasis, nutrient remobilization during leaf senescence, and abiotic stress responses. Autophagosomes are the hallmark feature of autophagy, and their formation is regulated by the AuTophaGy-related (ATG) genes. The expression profiles of $A T G$ genes have been reported in several agronomic and model plants. To gain insight into the role of autophagy in senescence and abiotic stress responses in floriculture crops, we investigated the regulation of petunia (Petunia $\times$ hybrida) ATG genes (PhATG4, PhATG5, PhATG6, PhATG7, PhATG8a, and PhATG13) during flower senescence and in response to low fertility, nutrient deficiency (-N, -P, and -K), and chronic (weeks) or acute (hours) salt stress using quantitative polymerase chain reaction (PCR). Age-induced corolla wilting coincided with the increased expression of all $A T G$ genes. Petunia $A T G$ genes were upregulated by low fertility and $N$ and $P$ deficiency. Acute salt stress rapidly increased the expression of the petunia $A T G$ genes, but chronic salt stress treatments did not. This project provides insight into the role of autophagy in flower senescence and abiotic stress responses in floriculture crops.
\end{abstract}

Autophagy is a nutrient recycling process. During autophagy, double membrane structures (autophagosomes) capture, transport, and deliver cytosolic contents to the vacuoles for degradation (Liu and Bassham, 2012). Autophagosome development is regulated by the $A T G$ genes (Klionsky et al., 2003). More than 30 $A T G$ genes have been identified in yeast (Saccharomyces cerevisiae), and 18 of these (ATG1-10, ATG12-14, ATG1618, ATG29, and ATG31) are essential for autophagosome formation (Feng et al., 2014; Suzuki et al., 2017; Yoshimoto, 2012). In plants, autophagy is involved in senescence and abiotic stress responses (Avila-Ospina et al., 2014; Liu et al., 2009).

Autophagy is involved in the bulk degradation of intracellular proteins and organelles that have been transported to the vacuole. Seventy-five percent to $80 \%$ of total leaf nitrogen is recycled via autophagy of whole chloroplasts (chlorophagy) or of rubisco-containing bodies (Wada et al., 2009). In support of its central role in leaf senescence, high-resolution temporal profiling in arabidopsis (Arabidopsis thaliana) has identified 15 autophagy genes that are upregulated at various stages of leaf senescence (Breeze et al., 2011). Accelerated leaf senescence has been observed in a number of atg mutants (Doelling et al., 2002; Yoshimoto et al., 2004). An RNA-seq experiment in petunia has also identified eight $A T G$ genes that were upregulated during the pollination-induced senescence of corollas (Broderick et al., 2014). These genes mapped throughout the autophagy Kyoto Encyclopedia of Genes and Genomes (KEGG) pathway, including autophagy induction, vesicle nucleation, and vesicle expansion and completion. Transcript abundance of multiple members of the petunia $A T G 8$ gene family (PhATG8a, PhATG8b, PhATG8c, and PhATG8d) increase in senescing pollinated flowers concomitant with corolla

Received for publication 1 Feb. 2018. Accepted for publication 26 Mar. 2018. Salaries and research support were provided in part by State and Federal funds appropriated to the Ohio Agricultural Research and Development Center, The Ohio State University. Journal article number HCS 18-02.

${ }^{1}$ Corresponding author. E-mail: jones1968@osu.edu. wilting and increased nitrogen content in the ovary (Shibuya et al., 2013). These studies suggest that autophagy may be involved in the remobilization of nutrients from the corolla to the developing seeds in petunia flowers (Shibuya, 2012; Shibuya et al., 2013).

Under abiotic stress, autophagy contributes to plant survival by making nutrients available or remobilizing damaged proteins (Guiboileau et al., 2012; Hanaoka, 2002; Xiong et al., $2005,2006)$. The $A T G$ genes of several species are upregulated in response to nitrogen or carbon limitation ( $\mathrm{Li}$ et al., 2016; Maillard et al., 2015; Rose et al., 2006). Autophagy-deficient plants are hypersensitive to nutrient starvation as evidenced by premature senescence-induced leaf yellowing (Hanaoka, 2002; Xiong et al., 2005). By contrast, over-expression of ATG8a from foxtail millet (Setaria italica) in rice (Oryza sativa) improves tolerance to $\mathrm{N}$ starvation (Li et al., 2016).

The expression of the $A T G$ genes is also upregulated in response to salt stress (Li et al., 2016; Liu et al., 2009). Transgenic AtATG18a-RNAi arabidopsis (Liu et al., 2009) and the osatg10 rice mutant (Shin et al., 2009) are both hypersensitive to salt stress. Salinity causes a combination of ionic and osmotic stress in the plant (Acosta-Motos et al., 2017; Maduraimuthu and Prasad, 2013). Salt stress increases the production of reactive oxygen species (ROS), which function as signaling molecules during abiotic stress responses (Miller et al., 2010). The overproduction of these ROS can cause oxidative stress (Acosta-Motos et al., 2017; Maduraimuthu and Prasad, 2013; Miller et al., 2010), and autophagy contributes to remobilization of organelles damaged by ROS (Luo et al., 2017; Xiong et al., 2006). Osmolyte production and $\mathrm{Na}$ compartmentation in the vacuole are salt stress tolerance mechanisms (Maduraimuthu and Prasad, 2013; Singh et al., 2015). Arabidopsis mutants ( $\operatorname{atg} 2, \operatorname{atg} 5, \operatorname{atg} 7$, and $\operatorname{atg} 9)$ have decreased accumulation of osmolytes (proline and soluble sugars) and reduced $\mathrm{Na}$ compartmentation (Luo et al., 2017).

For the floriculture industry, crop success and marketability depends on visual quality. Visual quality is mainly defined by 
flower longevity and the aesthetic beauty of flowers and foliage. Flower and leaf longevity is genetically determined, but it can be reduced by environmental stress (Lim et al., 2007; van Doorn and Woltering, 2008). Flower senescence can also be accelerated by pollination (Broderick et al., 2014; van Doorn and Woltering, 2008). The premature senescence of flowers and foliage caused by abiotic stresses reduces visual quality of finished plants, which translates into economic losses for growers and retailers (Cassaniti et al., 2013; Fisher et al., 2016; Villarino and Mattson, 2011; Wu et al., 2017). Because autophagy plays a key role in senescence and abiotic stress responses (Hanaoka, 2002; Li et al., 2016; Liu et al., 2009; Luo et al., 2017; Xia et al., 2012), ATG genes may be suitable targets for floriculture crop improvement programs.

The objective of this study was to investigate the regulation of $A T G$ gene expression in corollas during age-induced flower senescence and in leaves following nutrient limitation and salt stress. Petunia 'Mitchell Diploid' was used as a model system for these experiments because of petunia's economic importance in the floriculture industry and because 'Mitchell Diploid' is a good molecular model for studies of flower development and stress responses (Vandenbussche et al., 2016). These experiments provide support for the role of autophagy in senescence and stress responses in petunia.

\section{Materials and Methods}

Flower development And Senescence. Petunia 'Mitchell Diploid' seeds were sown in 128-well trays on top of soilless media (Promix BX; Premier Tech Horticulture, Rivière-duLoup, Canada) and grown under fluorescent lights. Once established, seedlings were transplanted to 1-L pots and grown in a growth chamber (Conviron, Winnipeg, Canada) under metal halide and high-pressure sodium lights $(14 / 10 \mathrm{~h}$ light/dark photoperiod). The plants were irrigated with $200 \mathrm{mg} \cdot \mathrm{L}^{-1} \mathrm{~N}$ from 20N-4.4P-16.6K water-soluble fertilizer (Jack's Professional Peat Lite; JR Peters, Inc., Allentown, PA) and grown to flowering. Flowers were tagged and de-anthered $1 \mathrm{~d}$ before anthesis (flower opening) to avoid self-pollination. Corollas from unpollinated flowers were collected at $0,3,6$, and $7 \mathrm{~d}$ after anthesis (Fig. 1). This includes flowers from opening $(0 \mathrm{~d})$ to early (6 d) and middle (7 d) senescence stages. Four to eight corollas were collected from at least three different plants and pooled together for each replication $(n=3)$. Corollas were frozen in liquid $\mathrm{N}_{2}$ and stored at $-80{ }^{\circ} \mathrm{C}$ until used for RNA extraction.

Ethylene treatment. Petunia plants were grown as described by Chapin et al. (2017). One day after anthesis, deanthered flowers were detached from the plant and peduncles

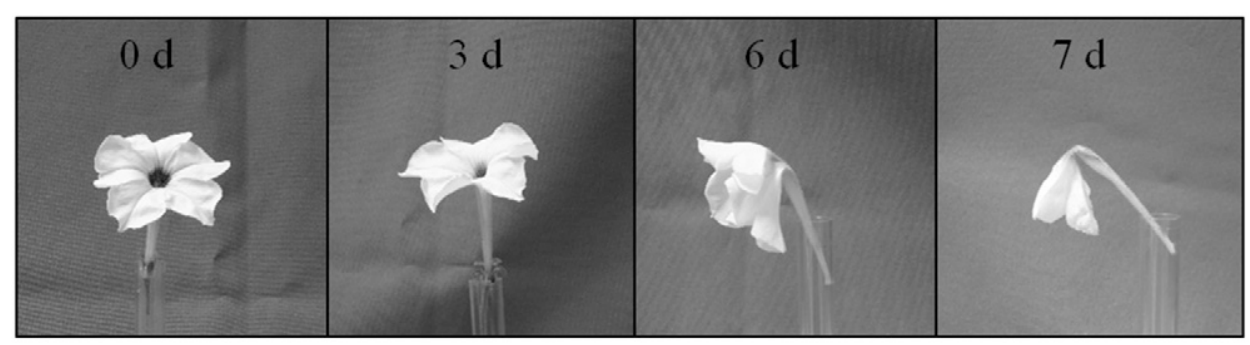

Fig. 1. Age-induced senescence of unpollinated flowers from petunia 'Mitchell Diploid'. Flowers were de-anthered $1 \mathrm{~d}$ before anthesis to avoid self-pollination. Photographs were taken at $0,3,6$, and $7 \mathrm{~d}$ after anthesis. were trimmed to equal lengths. Peduncles were placed in vials of nanopure water and the detached flowers were sealed in 24-L chambers. Ethylene was injected to achieve a final concentration of $0.1,1.0$, or $10.0 \mu \mathrm{L} \cdot \mathrm{L}^{-1}$. Potassium permanganate sachets (Ethylene Control, Selma, CA) were used in the control chamber [air $\left.\left(0 \mu \mathrm{L} \cdot \mathrm{L}^{-1}\right)\right]$ to remove any ethylene produced by the flowers (Chapin et al., 2017). Six flowers were included in each treatment. After $4 \mathrm{~h}$ of treatment, the corollas were harvested, frozen in liquid $\mathrm{N}_{2}$, and stored at $-80{ }^{\circ} \mathrm{C}$ for RNA extraction.

LOW FERTILITY TREATMENT. Petunia seeds were germinated and grown for 7 weeks as described for the flower senescence experiment. Seven-week-old plants were transplanted to $1-\mathrm{L}$ pots and grown in an environment controlled greenhouse with a long day photoperiod (16/8 h light/dark photoperiod) at 21 to $24^{\circ} \mathrm{C} / 16$ to $18^{\circ} \mathrm{C}$ (day/night). The experiment was organized as a complete randomized design with 16 replications per treatment. There were two irrigation treatments in the experiment. Plants were irrigated with $100 \mathrm{mg} \cdot \mathrm{L}^{-1} \mathrm{~N}$ (control) or $10 \mathrm{mg} \cdot \mathrm{L}^{-1}$ $\mathrm{N}$ (low fertility) from $15 \mathrm{~N}-2.2 \mathrm{P}-12.5 \mathrm{~K}-2.9 \mathrm{Ca}-1.2 \mathrm{Mg}$ watersoluble fertilizer (JR Peters, Inc.). Plants were irrigated as needed for 4 weeks. The first fully opened leaves were collected, pooled (two leaves per tube; each leaf from a different plant), and frozen with liquid $\mathrm{N}_{2}$. Samples were collected weekly and stored at $-80{ }^{\circ} \mathrm{C}$ until used for RNA extraction. Chlorophyll content was measured weekly on the first and second fully open leaf on each plant using a SPAD meter (Spectrum Technologies, Aurora, IL).

NutRient DeficienCy TREATMENT. Petunia seeds were germinated in a soilless mix as described previously. Four-weekold seedlings were transplanted into 0.5 -L pots (three seedlings per pot) filled with perlite and wetting polymer (Soil Moist; JRM Chemical, Cleveland, $\mathrm{OH}$ ). Pots were randomly assigned to 12 trays (two pots per tray). Nutrient solutions (complete, $\mathrm{N}$, $\mathrm{P}$, and $\mathrm{K}$ ) were prepared as described in Machlis and Torrey (1956) (Table 1). Plants were irrigated via capillary mat wicking into the perlite mixture and by top watering with fresh solution daily for 4 weeks. Four weeks after treatment, the leaves from all plants in each tray were harvested, frozen in liquid $\mathrm{N}_{2}$, and stored at $-80{ }^{\circ} \mathrm{C}$ for RNA extraction.

Chronic salt stress treatment. Petunia seeds were germinated and grown for 7 weeks as described for the flower senescence experiment. The experiment was a randomized complete block design with a $2 \times 8$ factorial arrangement of irrigation treatments (control and salt stress) and time (3, 6, 9, $12,15,21,24$, and $27 \mathrm{~d}$ ), with four blocks each containing eight plant replications. The irrigation treatments were nutrient solutions $\left(100 \mathrm{mg} \cdot \mathrm{L}^{-1} \mathrm{~N}\right.$ from $15 \mathrm{~N}-2.2 \mathrm{P}-12.5 \mathrm{~K}-2.9 \mathrm{Ca}-$ $1.2 \mathrm{Mg}$ water-soluble fertilizer) supplemented with $\mathrm{NaCl}$ at $0 \mathrm{~mm}$ (control) or $200 \mathrm{~mm}$ (salt stress). Plants were irrigated with these solutions as needed from the time of transplant to the end of the experiment. The first fully opened leaves were collected at $3,6,9,12$, $15,21,24$, and $27 \mathrm{~d}$. Leaves were pooled (two leaves per tube; each leaf from a different plant), frozen with liquid $\mathrm{N}_{2}$, and stored at $-80{ }^{\circ} \mathrm{C}$ until used for RNA extraction.

Chlorophyll content was measured on the second fully open leaf 
Table 1. Nutrient solution recipes for nutrient deficiency treatments. Petunia 'Mitchell Diploid' plants in 0.5 -L pots of perlite were irrigated with nutrient solutions for 4 weeks to determine the effects of N, P, and K deficiencies on the expression of AuTophaGy-related genes in leaves. Control plants received a complete nutrient solution.

\begin{tabular}{lcccc}
\hline & Complete (control) & Nitrogen deficient & Phosphorus deficient & Potassium deficient \\
\hline $\mathrm{Ca}\left(\mathrm{NO}_{3}\right)_{2}$ & $5 \mathrm{mM}$ & & $5 \mathrm{mM}$ & $5 \mathrm{~mm}$ \\
$\mathrm{KNO}_{3}$ & $5 \mathrm{mM}$ & $1 \mathrm{mM}$ & $5 \mathrm{mM}$ & \\
$\mathrm{KH}_{2} \mathrm{PO}_{4}$ & $1 \mathrm{mM}$ & $5 \mathrm{mM}$ & & \\
$\mathrm{CaCl}_{2}$ & & $1 \mathrm{mM}$ & $1 \mathrm{mM}$ & \\
$\mathrm{KCl}$ & & & $5 \mathrm{mM}$ \\
$\mathrm{NaNO}_{3}$ & & & & $1 \mathrm{mM}$ \\
$\mathrm{NaH}_{2} \mathrm{PO}_{4}$ & $5 \mathrm{mM}$ & $5 \mathrm{mM}$ & $5 \mathrm{mM}$ & $5 \mathrm{mM}$ \\
$\mathrm{MgSO}_{4}$ & & $0.006 \%(\mathrm{v} / \mathrm{v})$ & $0.006 \%(\mathrm{v} / \mathrm{v})$ & $0.006 \%(\mathrm{v} / \mathrm{v})$ \\
Metallic iron $_{\text {Micronutrients }}^{\mathrm{z}}$ & $0.006 \%(\mathrm{v} / \mathrm{v})$ & $0.1 \%(\mathrm{v} / \mathrm{v})$ & $0.1 \%(\mathrm{v} / \mathrm{v})$ & $0.1 \%(\mathrm{v} / \mathrm{v})$
\end{tabular}

Adapted from Machlis and Torrey (1956).

${ }^{\mathrm{z}}$ Micronutrients $\left(50 \mathrm{~mm} \mathrm{H}_{3} \mathrm{BO}_{3}, 9 \mathrm{mM} \mathrm{MnCl}_{2} 4 \mathrm{H}_{2} \mathrm{O}, 0.8 \mathrm{~mm} \mathrm{ZnCl}, 0.3 \mathrm{~mm} \mathrm{CaCl}_{2} 2 \mathrm{H}_{2} \mathrm{O}\right.$, and $1 \mathrm{~mm}$ $\left.\mathrm{NaMoO}_{4} 2 \mathrm{H}_{2} \mathrm{O}\right)$.

at $15,21,24$, and $27 \mathrm{~d}$. Stomatal conductance $\left(g_{\mathrm{s}}\right)$ was measured on the abaxial side of the second fully opened leaf using a leaf porometer (SC-1; Decagon Devices, Pullman, WA). Leaf temperature was measured on the adaxial side of the second fully open leaf using an infrared thermometer (Digi-Sense, Vernon Hills, IL). The petunia leaf blade is divided in two sections by the midrib, the temperature was measured on the middle of each section, and the average of the two values was used. $g_{\mathrm{s}}$ and leaf temperature were measured at $3,6,9,12,15,21,24$, and $27 \mathrm{~d}$.

Two fresh leaf disks ( $8 \mathrm{~mm}$ diameter) from the second fully expanded leaf were collected at 21,24 , and $27 \mathrm{~d}$ to measure electrolyte leakage. Disks were rinsed with nanopure water and then incubated in $8 \mathrm{~mL}$ nanopure water at room temperature for

Table 2. Primers used for quantitative PCR analysis of AuTophaGy-related $(A T G)$ gene expression in petunia 'Mitchell Diploid'. PhActin and PhEFl $\alpha$ were used as reference genes. PhCP10 is an ortholog of the arabidopsis senescence-associated cysteine protease, AtSAG12.

\begin{tabular}{|c|c|c|}
\hline Gene name & $\begin{array}{l}\text { Primer sequence } \\
\text { (forward/reverse) }\end{array}$ & $\begin{array}{c}\text { Primer source } \\
\text { (gene identification no.) }\end{array}$ \\
\hline PhActin & $\begin{array}{l}\text { 5'AGCCAACAGAGAGAAGATGACCCA3'" } \\
\text { 5'ACACCATCACCAGAGTCCACCACA3' }\end{array}$ & Chapin and Jones (2009) (CV299322) \\
\hline$P h E F 1 \alpha$ & $\begin{array}{l}\text { 5'CCTGGTCAAATTGGAAACGG3'/ } \\
\text { 5'CAGATCGCCTGTCAATCTTGG3' }\end{array}$ & Mallona et al. (2010) (SGN-U207468) \\
\hline PhATG4 & $\begin{array}{l}\text { 5'CTTCTCAAGAGGCGAAGTTGA3'/ } \\
\text { 5'AGCTGCCAGTAAAGGAAGATAC3' }\end{array}$ & Designed $^{\mathrm{x}}(\operatorname{comp} 25286)^{\mathrm{y}}$ \\
\hline PhATG5 & $\begin{array}{l}\text { 5'GAAGCTCATCTCCGAATCTCATC3'/ } \\
\text { 5' TGAGGGCTTTCCAGTGATTTAG 3' }\end{array}$ & Designed $^{\mathrm{x}}(\operatorname{comp} 38085)^{\mathrm{y}}$ \\
\hline PhATG6 & $\begin{array}{l}\text { 5'GAGCGAGACGCAATTTTAGC3'/ } \\
\text { 5'CACTCGACCGGAATCTTAGG3' }\end{array}$ & Broderick et al. (2014) $\left(\right.$ comp16076) ${ }^{\mathrm{y}}$ \\
\hline PhATG7 & $\begin{array}{l}\text { 5'CATGGAGCAGGTCGTATAGATG3' ' } \\
\text { 5'CATTTGGACTTGAGAGGGAGAG3' }\end{array}$ & Designed $^{\mathrm{x}}(\operatorname{comp} 15661)^{\mathrm{y}}$ \\
\hline PhATG8a & $\begin{array}{l}\text { 5'TGGCAGACAGCTGACTTTTC3'/ } \\
\text { 5'TTTTAAACAACCATTTGAAGAGAGA3' }\end{array}$ & Shibuya et al. (2013) (AB721297) ${ }^{z}$ \\
\hline PhATG13 & $\begin{array}{l}\text { 5'CGTGTTGGTTCTAGCAGACTATC3' } \\
\text { 5'CTCTGGCTTGGGAATCAGAATTA3' }\end{array}$ & Designed $^{\mathrm{x}}(\operatorname{comp} 31468)^{\mathrm{y}}$ \\
\hline PhCP10 & $\begin{array}{l}\text { 5' ACTTTGTGGACTTGCAACGGAAGC3'/ } \\
\text { 5'CCAAGCCTATCTCAATCCCATACA3' }\end{array}$ & Chapin et al. (2017) (AY662996) ${ }^{\mathrm{z}}$ \\
\hline
\end{tabular}

${ }^{\mathrm{z}}$ National Center for Biotechnology Information Resource Coordinators (2017).

${ }^{\mathrm{y}}$ Sol Genomics Network (Fernandez-Pozo et al., 2015).

${ }^{\mathrm{x}}$ Primers were designed for this manuscript using cDNA sequences identified by Broderick et al. (2014).
$2 \mathrm{~h}$. Initial conductance (EC1) of the solution was measured using a conductivity meter (AB30; Thermo Fisher Scientific, Waltham, MA). Samples were autoclaved at $121{ }^{\circ} \mathrm{C}$ for $20 \mathrm{~min}$. Final electrical conductivity (EC2) was measured once samples cooled to room temperature. Electrolyte leakage (EL) was calculated as follows: $\mathrm{EL}=(\mathrm{EC} 1 /$ EC2) $\times 100($ Li et al., 2010)

ACUTE SAlt STRESS TREaTMent. Petunia seeds were germinated and grown hydroponically in five plastic trays filled with perlite. Plants were grown using half-strength Hoagland's nutrient solution (Hoagland and Arnon, 1950) during the first $18 \mathrm{~d}$ after sowing. On day 19 , the nutrient solution was replaced with half-strength Hoagland's supplemented with $100 \mathrm{~mm} \mathrm{NaCl}$. Seedling shoots were harvested at 1, 3, 6, 12, and $14 \mathrm{~h}$ after salt treatment. For the $0 \mathrm{~h}$ time point, tissue was collected just before applying the salt solution. At each time point, five shoots (one from each tray) were harvested, frozen, and stored at $-80{ }^{\circ} \mathrm{C}$ until used for RNA extraction.

RNA EXTRACTION. Total RNA was extracted from tissue samples collected in the flower senescence, ethylene treatment, nutrient deficiency, and acute salt stress experiments as described by Chapin and Jones (2009). Total RNA was extracted from samples collected in low fertility and salt stress experiments as follows. About $100 \mathrm{mg}$ of tissue was used for total RNA extraction and on-column DNase treatment (RNeasy Plant Mini Kit; Qiagen, Hilden, Germany). RNA concentrations and purity were measured with a spectrophotometer (NanoDrop ND-1000; Thermo Fisher Scientific). For RNA integrity assessment, $2 \mu \mathrm{g}$ of total RNA was run in a $1 \%$ agarose/formaldehyde gel.

Quantitative PCR. For each sample, $1 \mu \mathrm{g}$ of total RNA was used for cDNA synthesis (iScript Reverse Transcription Supermix kit; Bio-Rad Laboratories, Hercules, CA). One microliter cDNA was used as template in $20-\mu \mathrm{L}$ reactions prepared with the SsoAdvanced Universal SYBR Green Supermix kit (Bio-Rad Laboratories). Negative controls were included for each gene in each plate $(1 \mu \mathrm{L}$ nuclease-free water used as template). Samples and negative controls were run in triplicate on a thermocycler (CFX96 Touch $^{\text {TM }}$ Real-Time PCR Detection System; Bio-Rad Laboratories). The thermocycler protocol was the following: $95^{\circ} \mathrm{C}$ for $30 \mathrm{~s}$ and 40 cycles of $95^{\circ} \mathrm{C}$ for $10 \mathrm{~s}$ and $58^{\circ} \mathrm{C}$ for $20 \mathrm{~s}$. Primer specificity was checked by a melt-curve analysis $\left(65\right.$ to $95{ }^{\circ} \mathrm{C}$ 

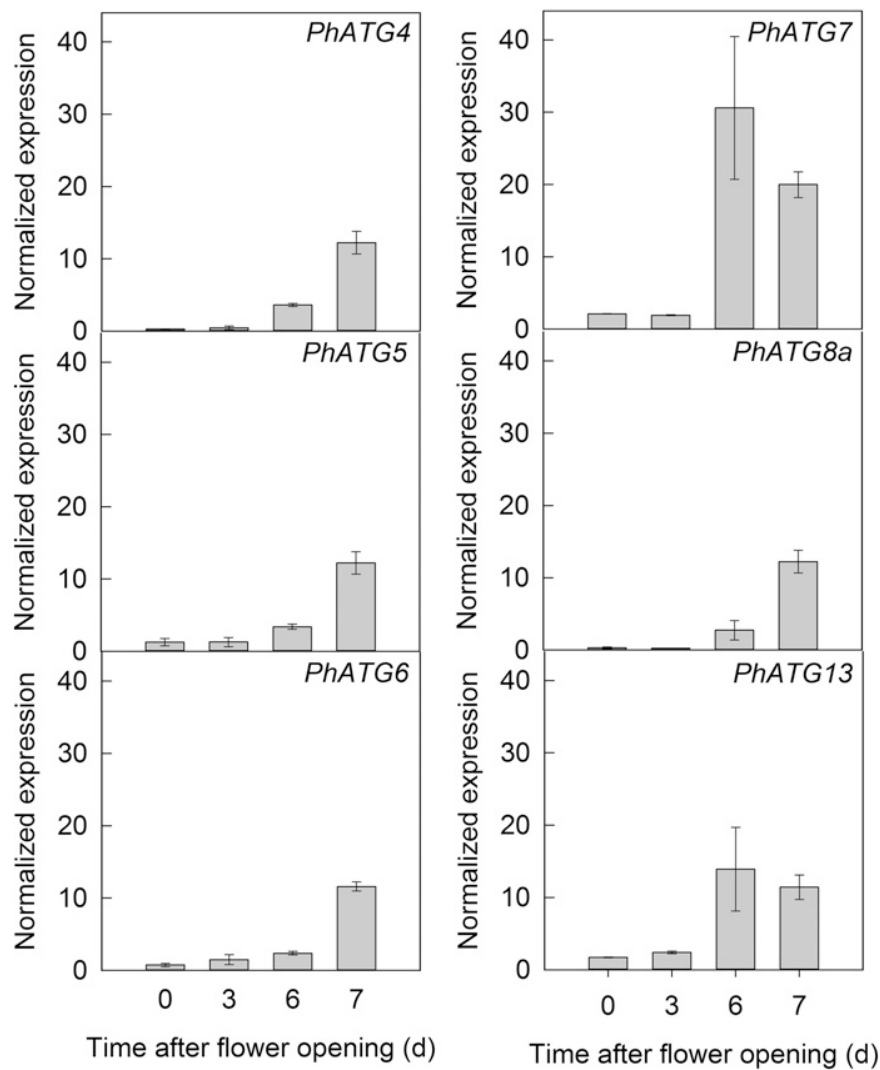

Fig. 2. Expression of AuTophaGy-related $(A T G)$ genes in petunia 'Mitchell Diploid' corollas during age-induced flower senescence. Flowers were deanthered $1 \mathrm{~d}$ before anthesis to avoid self-pollination. Unpollinated corollas were collected at $0,3,6$, and $7 \mathrm{~d}$ after anthesis. Expression of six $A T G$ genes (PhATG4, PhATG5, PhATG6, PhATG7, PhATG8a, and PhATG13) was analyzed by quantitative PCR. Two biological replications were run in triplicate and normalized to PhACTIN and PhEFl $\alpha$. Bars represent mean $\pm \mathrm{SE}$.

with $0.5{ }^{\circ} \mathrm{C}$ increments every $5 \mathrm{~s}$ ). Primer sequences and their sources are listed in Table 2. Petunia $A T G$ genes were identified in an RNAseq experiment from pollinated corollas (Broderick et al., 2014), and six genes were selected for further gene expression characterization in this study (Table 2). RNA-seq data are available in the Sequence Read Archive database at National Center for Biotechnology Information [NCBI BioProject ID:PRJNA259884 (National Center for Biotechnology Information Resource Coordinators, 2017)]. Sequences can also be found in the Sol Genomics Network P. hybrida transcriptome database (Fernandez-Pozo et al., 2015). These six genes are inclusive of all components of the regulation of autophagy KEGG pathway including autophagy induction (PhATG13), vesicle nucleation (PhATG6), and vesicle expansion and completion (PhATG7, PhATG5, PhATG8a, and PhATG3). The senescenceassociated cysteine protease, $P h C P 10$, was included as a molecular marker for senescence in petunia (Chapin et al., 2017; Jones et al., 2005). Relative gene expression was analyzed using CFX Manager software (Bio-Rad Laboratories). Actin (Chapin and Jones, 2009) and EF1 $\alpha$ (Mallona et al., 2010) were used as reference genes.

Statistical analysis. All statistical analyses were completed using algorithms in SAS (version 9.4; SAS Institute, Cary, NC). Analysis of variance and mean separation by least significant differences were performed. SPAD data from the
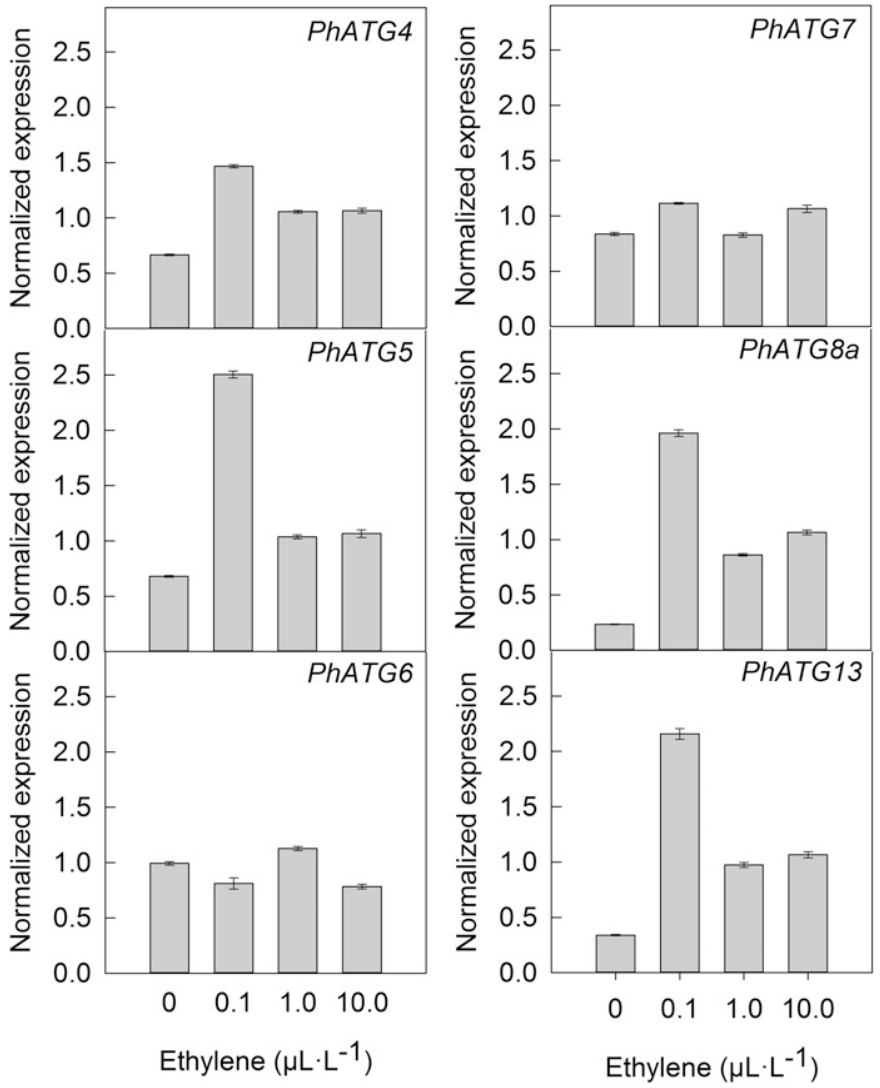

Fig. 3. Expression of AuTophaGy-related $(A T G)$ genes in petunia 'Mitchell Diploid' corollas treated with ethylene. Flowers were de-anthered $1 \mathrm{~d}$ before anthesis to avoid self-pollination. One day after anthesis, flowers were treated with $0,0.1,1.0$, or $10.0 \mu \mathrm{L} \cdot \mathrm{L}^{-1}$ ethylene for $4 \mathrm{~h}$. Expression of six $A T G$ genes (PhATG4, PhATG5, PhATG6, PhATG7, PhATG8a, and PhATG13) was analyzed by quantitative PCR. Samples were run in triplicate and normalized to PhACTIN and PhEFI $\alpha$. Bars represent mean $\pm \mathrm{SE}$.

low fertility experiment was treated as repeated measures, and it was analyzed using the GLIMMIX procedure and LSMEANS. Data from the salinity experiment (SPAD, leaf temperature, $g_{\mathrm{s}}$, and electrolyte leakage) was analyzed using the GLM procedure and LSMEANS. $g_{\mathrm{s}}$ and electrolyte leakage data were $\log$ transformed before the analysis. The significance level was set at $P \leq 0.05$.

\section{Results}

ATG GENES WERE UPREGULATED IN COROLLAS DURING THE SENESCENCE OF UNPOLLINATED PETUNIA FLOWERS. The six petunia $A T G$ genes were expressed at basal levels at flower opening $(0 \mathrm{~d})$ and at $3 \mathrm{~d}$ (Fig. 2). Petunia flowers were wilted by day 6 (Fig. 1), and the wilting coincided with the increased expression of all the $A T G$ genes (Fig. 2). At $6 \mathrm{~d}$, the expression levels of PhATG4, PhATG5, PhATG6, PhATG7, PhATG8a, and PhATG13 were 13.2-, 2.7-, 3.2-, 14.5-, 8.8-, and 8.1-fold higher, respectively, than at $0 \mathrm{~d}$ (Fig. 2). Transcript levels for PhATG4, PhATG5, PhATG6, and PhATG8a continued to increase at $7 \mathrm{~d}$, whereas PhATG7 declined. PhATG13 expression levels were similar at 6 and $7 \mathrm{~d}$ after anthesis.

EXOGENOUS ETHYLENE TREATMENT INDUCED EXPRESSION OF ATG GENES IN PETUNIA COROLlas. Treatment with only 0.1 $\mu \mathrm{L} \cdot \mathrm{L}^{-1}$ ethylene for $4 \mathrm{~h}$ resulted in increased PhATG4, PhATG5, 


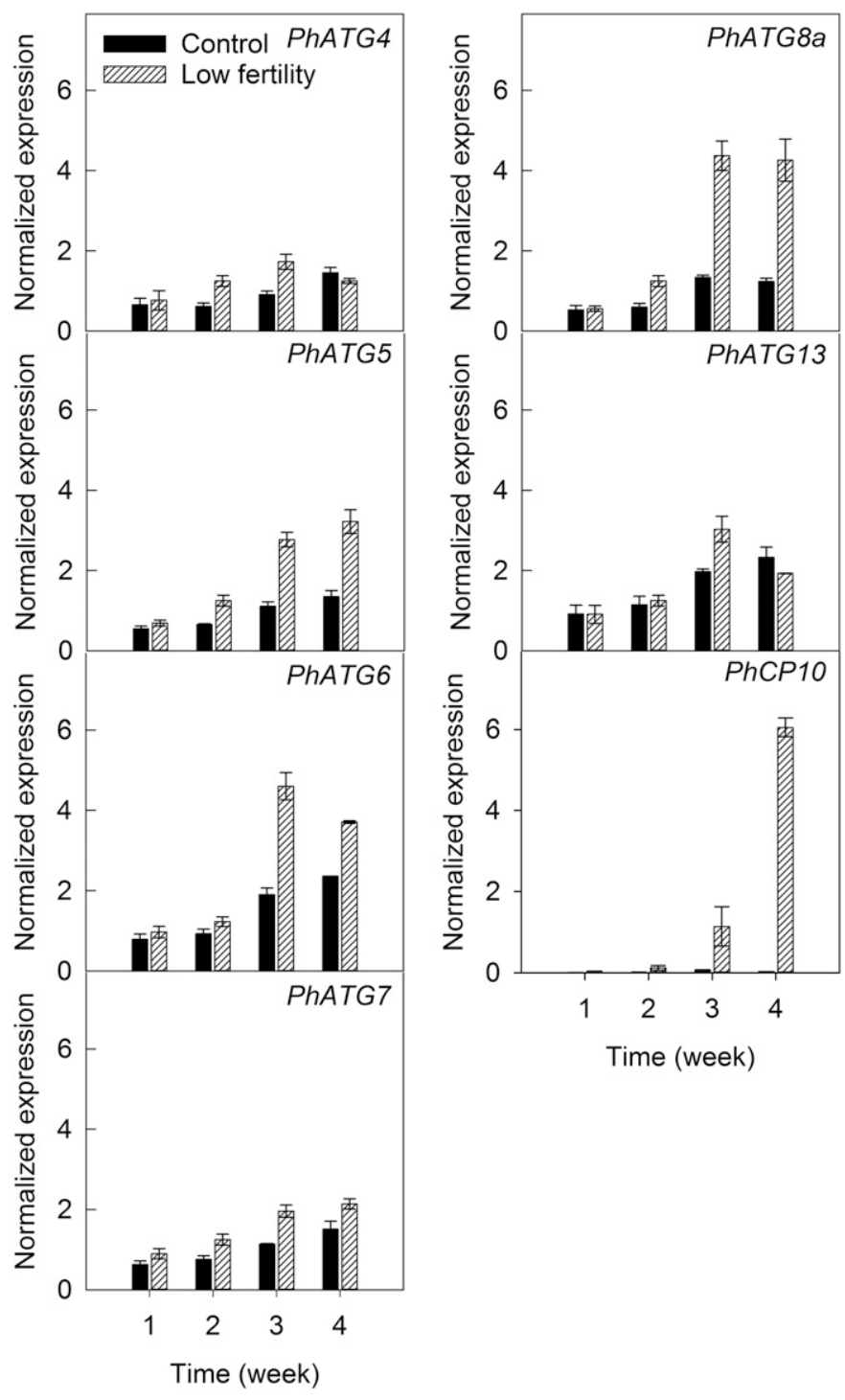

Fig. 4. Expression of AuTophaGy-related $(A T G)$ genes in petunia 'Mitchell Diploid' grown under low fertility stress. Leaves were collected from control $\left(100 \mathrm{mg} \cdot \mathrm{L}^{-1} \mathrm{~N}\right.$ from $15 \mathrm{~N}-2.2 \mathrm{P}-12.5 \mathrm{~K}-2.9 \mathrm{Ca}-1.2 \mathrm{Mg}$ ) and low fertility stressed $\left(10 \mathrm{mg} \cdot \mathrm{L}^{-1} \mathrm{~N}\right.$ from $\left.15 \mathrm{~N}-2.2 \mathrm{P}-12.5 \mathrm{~K}-2.9 \mathrm{Ca}-1.2 \mathrm{Mg}\right)$ plants weekly and expression of six ATG genes (PhATG4, PhATG5, PhATG6, PhATG7, $P h A T G 8 a$, and $P h A T G 13)$ and the senescence marker $P h C P 10$ were analyzed by quantitative PCR. Two biological replications were run in triplicate and normalized to PhACTIN and PhEFl $\alpha$. Bars represent mean $\pm \mathrm{sE}$.

PhATG8a, and PhATG13 transcript abundance (Fig. 3). The abundance of these four genes in corollas treated with 1.0 or 10.0 $\mu \mathrm{L} \cdot \mathrm{L}^{-1}$ ethylene was still upregulated compared with untreated corollas $\left(0 \mu \mathrm{L} \cdot \mathrm{L}^{-1}\right)$, but was lower than in those treated with 0.1 $\mu \mathrm{L} \cdot \mathrm{L}^{-1}$ ethylene. PhATG7 was only slightly upregulated by the 0.1 and $10 \mu \mathrm{L} \cdot \mathrm{L}^{-1}$ ethylene treatment, and PhATG6 was induced only in corollas treated with $1.0 \mu \mathrm{L} \cdot \mathrm{L}^{-1}$ ethylene.

LOW FERTILITY TREATMENTS INDUCED EXPRESSION OF PETUNIA $\boldsymbol{A T G}$ GENEs. All six petunia $A T G$ genes were detected in leaves from control $\left(100 \mathrm{mg} \cdot \mathrm{L}^{-1} \mathrm{~N}\right)$ and low fertility $\left(10 \mathrm{mg} \cdot \mathrm{L}^{-1} \mathrm{~N}\right)$ treatments (Fig. 4). At week 1, there were no differences in plant size (Fig. 5) or leaf chlorophyll content (Fig. 6). By week 2 , plants fertilized with $10 \mathrm{mg} \cdot \mathrm{L}^{-1} \mathrm{~N}$ were visibly smaller than those fertilized with $100 \mathrm{mg} \cdot \mathrm{L}^{-1}$ (Fig. 5), and the chlorophyll content of nutrient stressed plants decreased by $17 \%$ compared

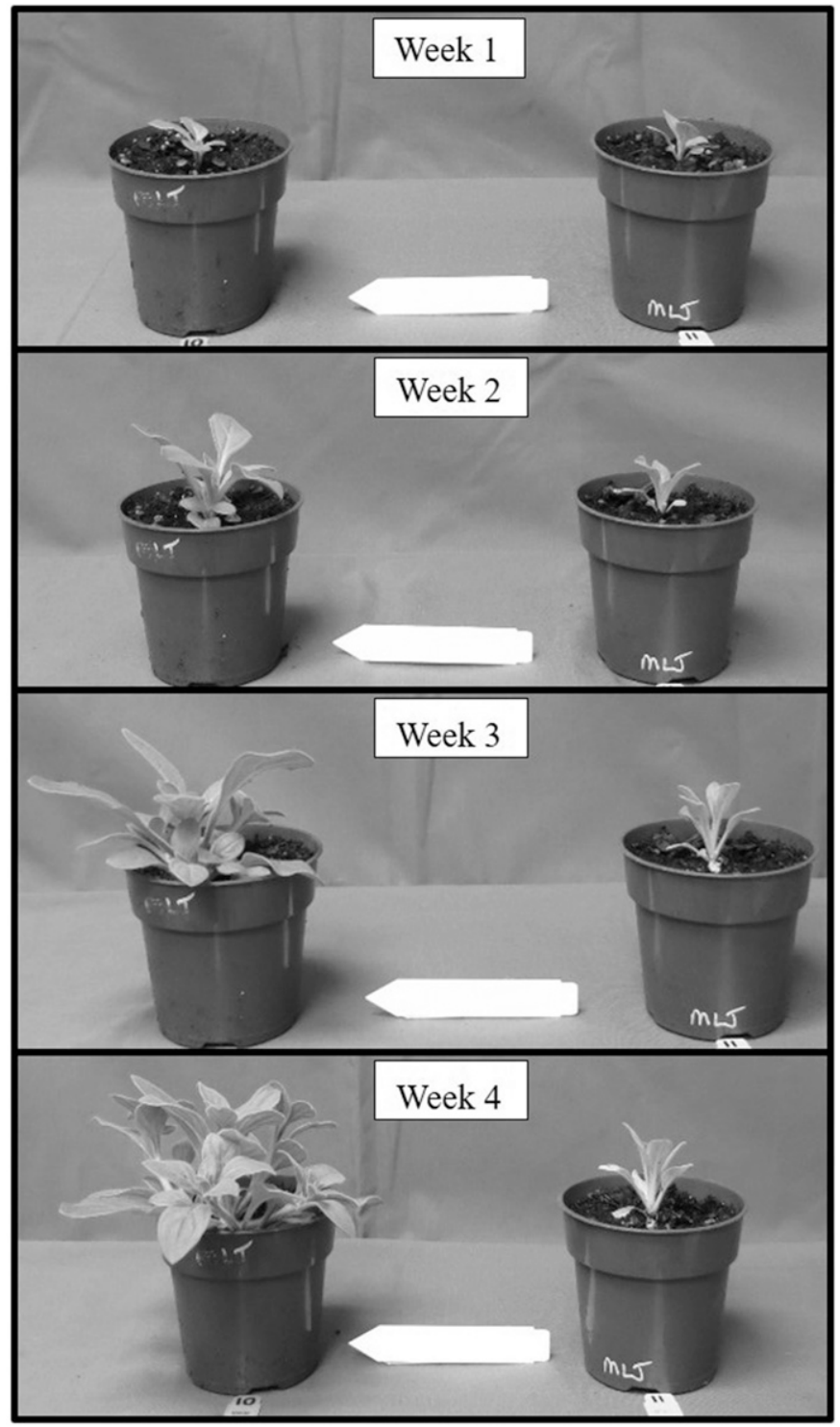

Control

Low fertility

Fig. 5. Effect of low fertility stress in petunia 'Mitchell Diploid'. Visual comparison of plants irrigated with $100 \mathrm{mg} \cdot \mathrm{L}^{-1} \mathrm{~N}$ [Control (left)] vs. plants irrigated with $10 \mathrm{mg} \cdot \mathrm{L}^{-1} \mathrm{~N}$ [Low fertility (right)] from $15 \mathrm{~N}-2.2 \mathrm{P}-12.5 \mathrm{~K}-$ $2.9 \mathrm{Ca}-1.2 \mathrm{Mg}$ water-soluble fertilizer.

with control plants (Fig. 6). These differences were accompanied by changes in the expression levels of PhATG4, PhATG5, PhATG7, and PhATG8a (Fig. 4). Expression levels of PhATG4, PhATG5, PhATG7, and PhATG8a were 2-, 1.9-, 1.6-, and 2.1-fold higher, respectively, in stressed plants compared with control plants at week 2 . Differences in plant size and chlorophyll content between the control and low fertility treatments continued to increase at weeks 3 and 4 (Figs. 5 and 6). At week 3 , the expression of the six $A T G$ genes in stressed plants was higher than in control plants, with the greatest upregulation detected in PhATG6 and PhATG8a transcripts (Fig. 4). By week 4, PhATG5, PhATG6, PhATG7, and PhATG8a transcript levels were still greater in leaves from stressed plants (2.4-, 1.6-, 1.4-, and 3.4-fold higher, respectively), whereas PhATG4 and $P h A T G 13$ transcript levels were higher in control leaves. 


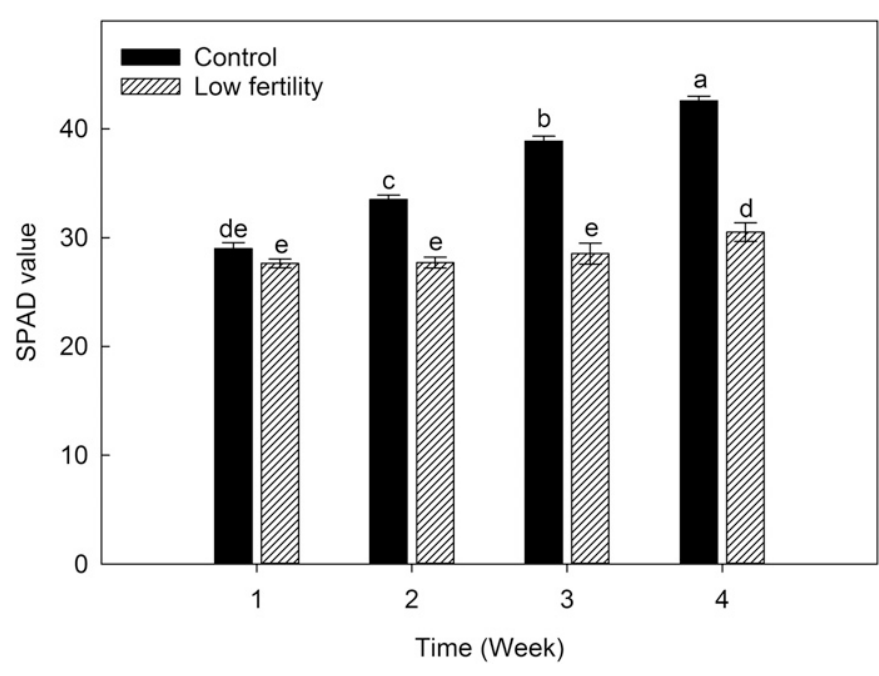

Fig. 6. Effect of low fertility stress on chlorophyll content of petunia 'Mitchell Diploid' leaves. Seven-week-old plants were irrigated with either $100 \mathrm{mg} \cdot \mathrm{L}^{-1}$ $\mathrm{N}$ (Control) or $10 \mathrm{mg} \cdot \mathrm{L}^{-1} \mathrm{~N}$ (Low fertility) from $15 \mathrm{~N}-2.2 \mathrm{P}-12.5 \mathrm{~K}-2.9 \mathrm{Ca}-$ $1.2 \mathrm{Mg}$ for 4 weeks. Chlorophyll content was measured weekly. Bars represent mean $\pm \operatorname{SE}(n=16)$. Bars with the same letters are not significantly different as tested by least significant differences at $P \leq 0.05$.

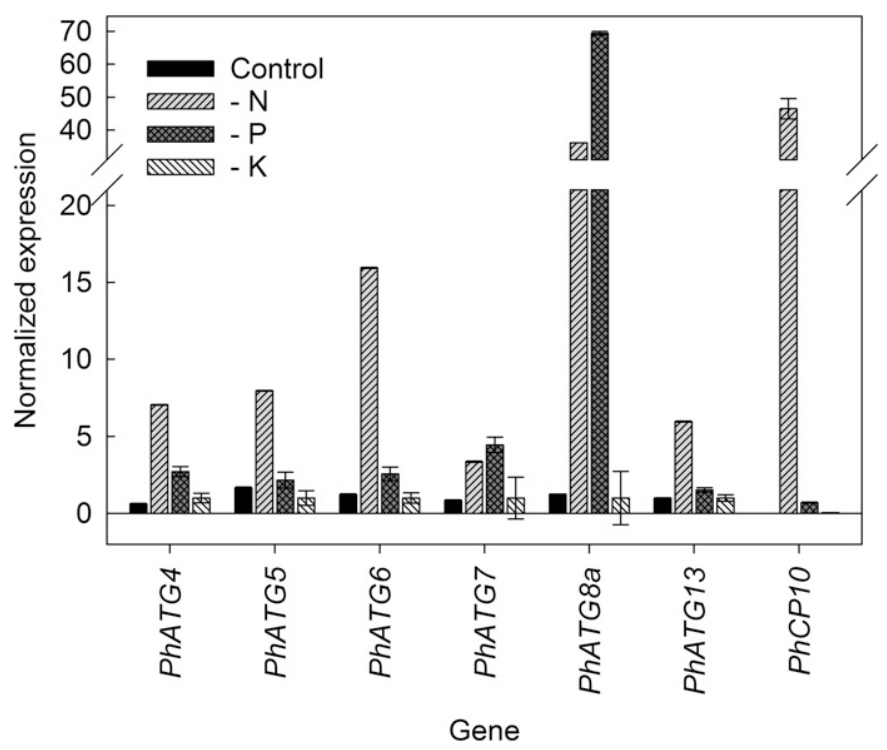

Fig. 7. Expression of AuTophaGy-related $(A T G)$ genes in petunia 'Mitchell Diploid' in response to nutrient deficiency. Petunia plants were grown hydroponically with nutrient solutions deficient in N, P, or K (recipe details in Table 1). The control treatment was a complete nutrient solution. Leaves were collected 4 weeks after treatment, and expression of six $A T G$ genes (PhATG4, PhATG5, PhATG6, PhATG7, PhATG8a, and PhATG13) and the senescence maker $P h C P 10$ were analyzed by quantitative PCR. Samples were run in triplicate and normalized to PhACTIN and PhEFl $\alpha$. Bars represent mean \pm SE.

PhATG8a exhibited the highest increase in expression levels in response to low fertility. The senescence marker gene $P h C P 10$ (Chapin et al., 2017) was expressed at very low levels (close to 0) in control plants throughout the experiment. Under nutrient stress conditions, PhCP10 was slightly upregulated by week 3 and peaked at week 4.

NITROGEN AND PHOSPHORUS DEFICIENCY INDUCED EXPRESSION OF PETUNIA $\boldsymbol{A T G}$ GENES. The low fertility treatment increased the expression of $A T G$ genes, but this treatment $\left(10 \mathrm{mg} \cdot \mathrm{L}^{-1} \mathrm{~N}\right.$
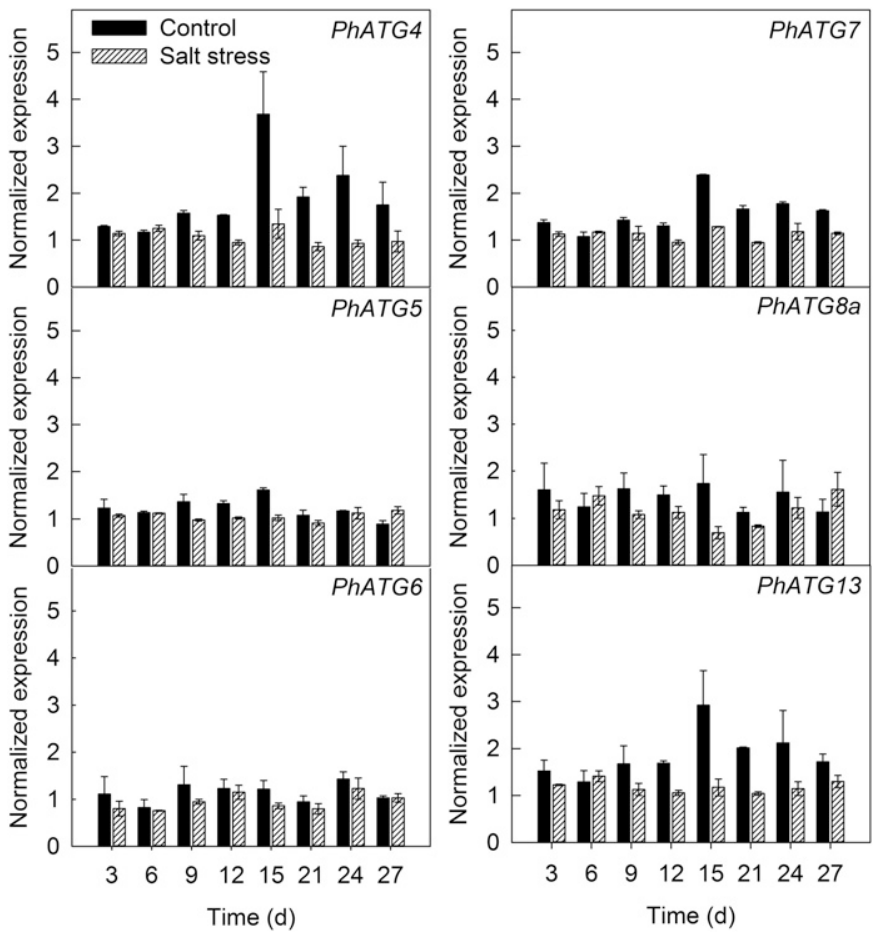

Fig. 8. Expression of AuTophaGy-related (ATG) genes in petunia 'Mitchell Diploid' in response to chronic salt stress. Leaves were collected from control and salt stressed plants and expression of six $A T G$ genes (PhATG4, PhATG5, PhATG6, PhATG7, PhATG8a, and PhATG13) was analyzed by quantitative PCR. Two biological replications were run in triplicate and normalized to PhACTIN and PhEFl $\alpha$. Bars represent mean $\pm \mathrm{SE}$.

from $15 \mathrm{~N}-2.2 \mathrm{P}-12.5 \mathrm{~K}-2.9 \mathrm{Ca}-1.2 \mathrm{Mg}$ water-soluble fertilizer) reduced the availability of multiple macro and micronutrients. A second nutrient deficiency experiment was therefore conducted to look specifically at the effects of $\mathrm{N}, \mathrm{P}$, and $\mathrm{K}$ deficiencies on $A T G$ gene expression in petunia leaves. All deficient plants were stunted compared with controls and had symptoms of leaf chlorosis. Phosphorus deficiency caused purpling of the leaves. All six $A T G$ genes were expressed at basal levels under control conditions (complete, containing $\mathrm{N}$, $\mathrm{P}$, and K) (Fig. 7). Compared with the control, K deficiency did not influence expression of the $A T G$ genes. However, $\mathrm{N}$ and $\mathrm{P}$ deficiency caused an increase in expression of all $A T G$ genes analyzed. PhATG8a expression levels in plants under $\mathrm{N}$ and $\mathrm{P}$ deficiency were 29- and 56- fold higher than control plants, respectively. PhATG7 transcripts were similarly induced by $\mathrm{N}$ and $\mathrm{P}$ deficiency. $\mathrm{N}$ deficiency increased the expression of PhATG4, PhATG5, PhATG6, and PhATG13 more than $\mathrm{P}$ deficiency. PhATG4, PhATG5, PhATG6, and PhATG13 transcript abundance was 11-, 5-, 13-, and 6-fold higher in N deficient leaves, and only 4.3-, 1.3-, 2.1-, and 1.5-fold higher in $\mathrm{P}$ deficient leaves when compared with control leaves. PhCP10 was not detected in the control treatment, and its transcript levels were low in the $\mathrm{P}(0.7)$ and $\mathrm{K}(0.05)$ deficiency treatments. However, nitrogen deficiency greatly increased PhCP10 expression (46.5).

Chronic SAlt STRESS TREatments DID NOT INCREASE EXPRESSION OF THE PETUNIA $\boldsymbol{A T G}$ GENES. Transcripts from all six genes were detected under both control $(0 \mathrm{~mm} \mathrm{NaCl})$ and chronic (weeks of exposure) salt stress conditions (Fig. 8). The effects of the chronic salt stress were evaluated using four plant 


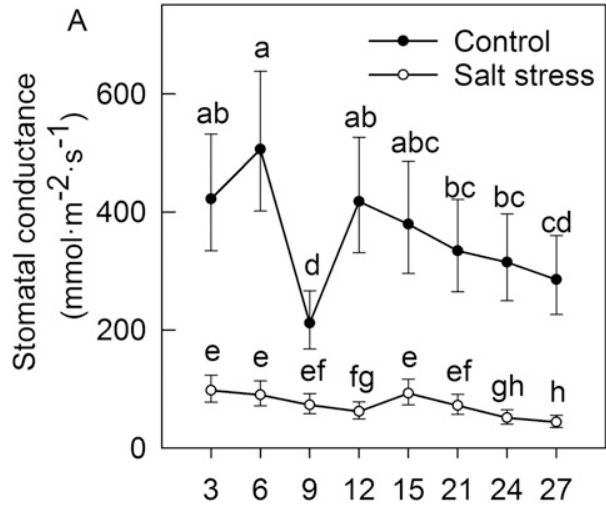

Time (d)

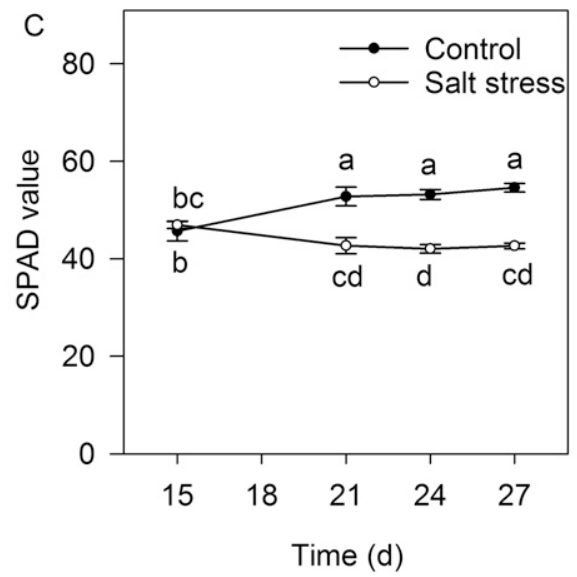

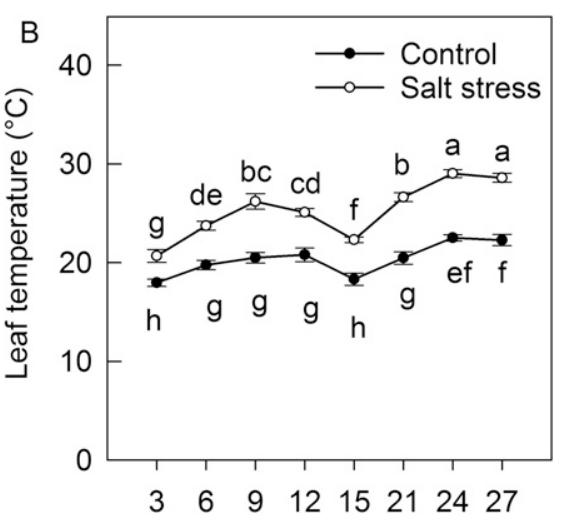

Time (d)

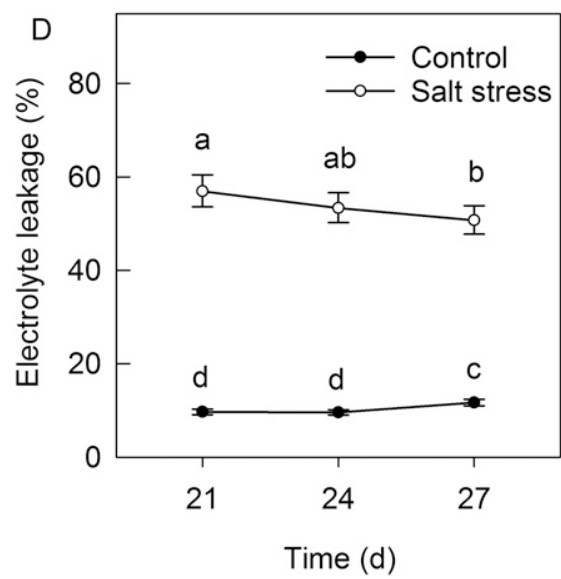

Fig. 9. Physiological effects of chronic salt stress on petunia 'Mitchell Diploid'. Seven-week-old plants were transplanted and grown for $27 \mathrm{~d}$ with a nutrient solution containing $0 \mathrm{~mm}$ (Control, solid circle) or $200 \mathrm{~mm} \mathrm{NaCl}$ (Salt stress, open circle). The following parameters where evaluated during the experiment: stomatal conductance $(\mathbf{A})$, leaf temperature $(\mathbf{B})$, chlorophyll content $(\mathbf{C})$, and electrolyte leakage (D). Points represent mean $\pm 95 \%$ confidence interval $(n=8)$ (A and D). Points represent mean $\pm \operatorname{SE}(n=8)(\mathbf{B}$ and $\mathbf{C})$. Points with the same letters are not significantly different as tested by least significant differences at $P \leq 0.05$.

The expression of PhATG4 was $\approx 2-$ fold higher at $24 \mathrm{~h}$ when compared with expression in untreated seedlings $(0 \mathrm{~h})$. PhATG5 and PhATG7 expression peaked at $3 \mathrm{~h}$; whereas expression of PhATG6, PhATG8a, and $P h A T G 13$ was higher at $24 \mathrm{~h}$. $P h C P 10$ was upregulated slightly after $12 \mathrm{~h}$ of salt treatment, and a much greater increase in expression was detected at $24 \mathrm{~h}$ (Fig. 10).

\section{Discussion}

Autophagy is a nutrient recycling process by which macromolecules or entire organelles are degraded to reuse their building components. On the onset of leaf senescence, autophagy plays an important role in the remobilization of nutrients from senescing leaves to new or developing tissues (Guiboileau et al., 2012; Ishida et al., 2014). In addition, autophagy is important for abiotic stress tolerance as autophagy deficient plants are hypersensitive to nutrient limitation and salt stress (Liu and Bassham, 2012). The defining structure of autophagy is the autophagosome. Here, we analyzed the expression profiles of six (PhATG4, PhATG5, PhATG6, PhATG7, PhATG8a, and PhATG13) genes involved in autophagosome formation. All six were upregulated during flower senescence and following exposure to salt or nutrient

health indicators. $g_{\mathrm{s}}$ in salt stressed plants $(200 \mathrm{~mm} \mathrm{NaCl})$ was lower than control plants, and leaf temperature of salt-stressed plants was consistently higher than control plants throughout the experiment (Fig. 9A and B). Salt-stressed plants showed lower chlorophyll content than control plants starting on day 21 (Fig. 9C) and had higher electrolyte leakage (Fig. 9D).

Although the plant health indicators confirmed the plant responses to the chronic salt-stress, this treatment did not upregulate the expression of any of the $A T G$ genes evaluated (Fig. 8). PhATG6 did not show any significant changes in expression in response to chronic salt-stress. Expression of PhATG4, PhATG5, PhATG7, PhATG8a, and PhATG13 was either the same or lower in leaves from salt-stressed plants compared with control plants.

Petunia $\boldsymbol{A}$ TG gene expression was increased by aCute SALT STRESS. During chronic salt stress, expression was evaluated every $3 \mathrm{~d}$ for $27 \mathrm{~d}$, but none of the $A T G$ genes were upregulated by that treatment. The effects of acute (hours of exposure) salt shock on the expression of the ATG genes were evaluated during the first $24 \mathrm{~h}$ after salt treatment (Fig. 10). All $A T G$ genes were expressed at basal levels at $0 \mathrm{~h}(0 \mathrm{~mm} \mathrm{NaCl})$. After $1 \mathrm{~h}$ of exposure to $100 \mathrm{~mm} \mathrm{NaCl}$, a slight increase in the expression of PhATG4, PhATG5, and PhATG6 was detected. All $A T G$ genes showed a larger increase in expression by $3 \mathrm{~h}$. stress, supporting a role for autophagy in these processes in petunia. ATG13 is part of the Atg1 complex that regulates the initiation of autophagosome formation (Feng et al., 2014), and ATG6 is part of the class III PI3K (phosphatidylinositol 3-kinase) complex I involved in vesicle nucleation (Burman and Ktistakis, 2010; Suzuki et al., 2017). ATG4, ATG5, ATG7, and $A T G 8$ are part of the Atg12 and Atg8 ubiquitin-like conjugation system that functions in autophagosome expansion (Feng et al., 2014).

Flower senescence is genetically determined, and it can be accelerated by pollination. Several petunia $A T G$ genes have been identified and reported to be regulated during pollinationinduced flower senescence (Broderick et al., 2014; Shibuya et al., 2013). We found that PhATG4, PhATG5, PhATG6, PhATG7, PhATG8a, and PhATG13 were also upregulated during the age-induced senescence of unpollinated flowers (Fig. 2). Petunia flower senescence is accompanied by an increase in ethylene production, which coincides with the upregulation of PhATG8a-d (Shibuya et al., 2013). Under our experimental conditions, unpollinated petunia flowers showed the first visual signs of senescence (i.e., wilting) at $6 \mathrm{~d}$ after flower opening (Fig. 1). PhATG7 and PhATG13 were upregulated to a greater extent at this early senescence stage, compared with PhATG4, PhATG5, PhATG6, and PhATG8a, which had 


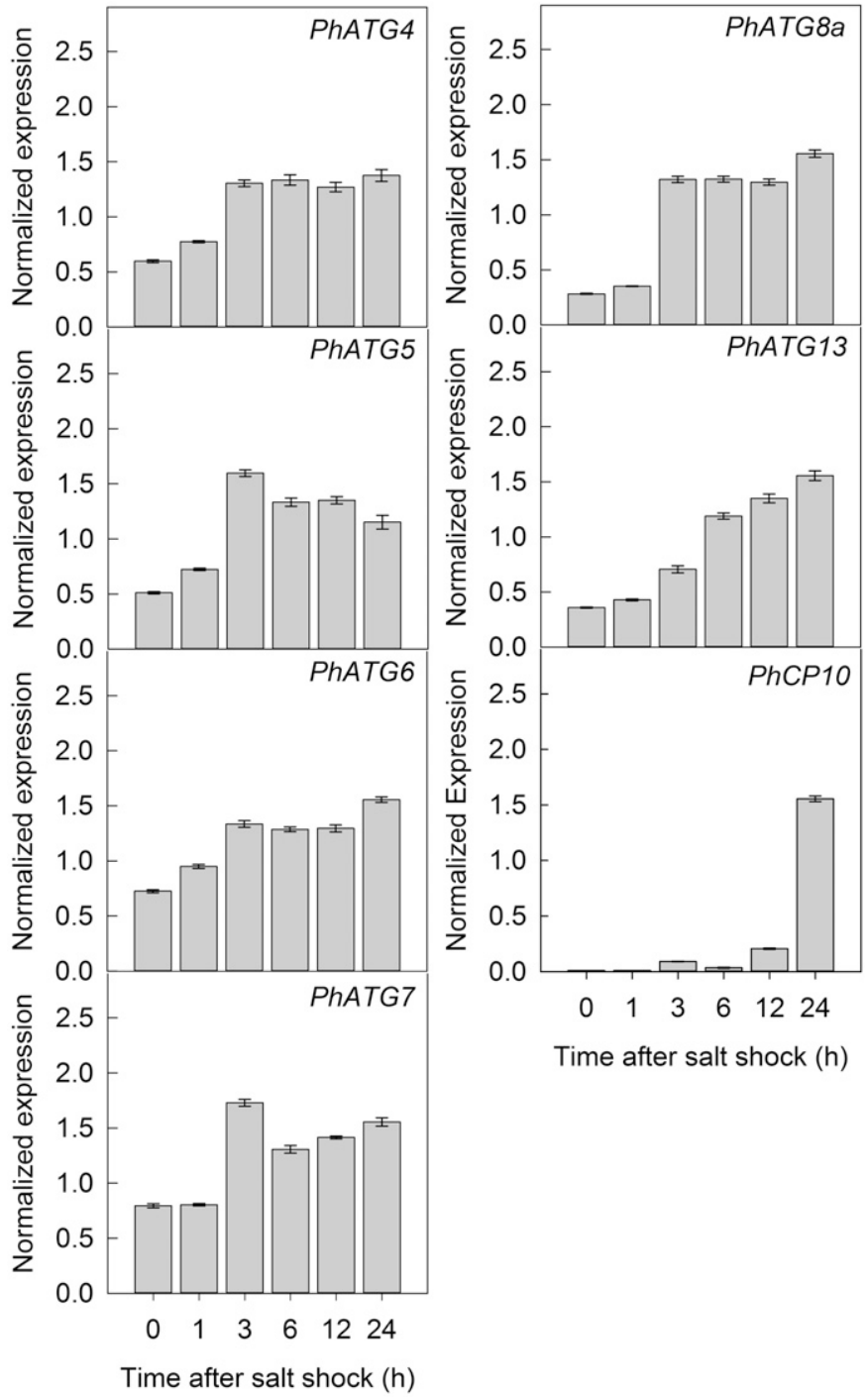

Fig. 10. Expression of AuTophaGy-related $(A T G)$ genes in petunia 'Mitchell Diploid' in response to acute salt stress. Petunia seedlings were grown in halfstrength Hoagland's nutrient solution for $18 \mathrm{~d}$. On day 19, nutrient solution was replaced with half-strength Hoagland's supplemented with $100 \mathrm{~mm} \mathrm{NaCl}$. The shoots of the seedlings were harvested at $0,1,3,6,12$ and $14 \mathrm{~h}$ after salt treatment. The expression of six ATG genes (PhATG4, PhATG5, PhATG6, PhATG7, PhATG8a, and PhATG13) and the senescence maker PhCP10 were analyzed by quantitative PCR. Samples were run in triplicate and normalized to PhACTIN and PhEFl $\alpha$. Bars represent mean \pm SE.

the greatest upregulation at $7 \mathrm{~d}$ after opening when corollas were more severely wilted (Fig. 2). ATG7p in yeast is required for the activation of ATG8p, which allows for the subsequent conjugation with phosphatidylethanolamine required to form autophagosomes (Ichimura et al., 2000). The 15 ATG genes upregulated during arabidopsis leaf senescence were also differentially expressed as senescence progressed. Expression of arabidopsis $A T G 7$ in leaves coincides with the early senescence stage, after protein levels start to decline but before chlorophyll levels change (Breeze et al., 2011). The timing of $A T G 7$ expression may control the activation of autophagy in senescing leaves and petals.

Nutrients, primarily $\mathrm{N}$ and $\mathrm{P}$, are remobilized from the corollas of pollinated and unpollinated petunia flowers during senescence (Chapin and Jones, 2007, 2009; Verlinden, 2003).
During the pollination-induced senescence of detached petunia flowers, a decrease in corolla nitrogen content coincides with an increase in ovary nitrogen content (Shibuya et al., 2013). Furthermore, when detached petunia flowers are held in concanamycin A (an autophagy inhibitor), there are no changes in the nitrogen content of the corolla or the ovary (Shibuya et al., 2013). Concanamycin A is used to visualize autophagic processes. In cells that are undergoing autophagy, it leads to the accumulation of autophagic bodies in the vacuole by inhibiting the degradation of vacuolar proteins (Yoshimoto et al., 2004). When treated with concanamycin A, pollinated petunia petals that were wilted contained more autophagosome-like structures in the vacuoles than unpollinated, nonsenescing petals (Shibuya et al., 2013). The monodansylcadaverine (MDC)-staining of these structures suggests an increase in autophagic flux during petal senescence, but MDC also stains other acidic structures in the cell. Although confirmation of the presence of autophagosomes in petals will require further investigation, the observed upregulation of $A T G$ genes involved in the initiation, vesicle nucleation, and vesicle expansion stages of autophagy (Fig. 2) provides further support for the involvement of autophagic mechanisms in cellular degradation and subsequent nutrient remobilization from the corolla to developing tissues during flower senescence.

The expression of PhATG8a, PhTAG8b, PhTAG8c, and PhTAG8d is induced in corollas by the treatment of detached flowers with exogenous ethylene $\left(2 \mu \mathrm{L} \cdot \mathrm{L}^{-1}\right)$ (Shibuya et al., 2013). All six petunia $A T G$ genes evaluated in this study were also upregulated by ethylene in a concentration dependent manner (Fig. 3). Corollas treated with $0.1 \mu \mathrm{L} \cdot \mathrm{L}^{-1}$ ethylene for only 4 h showed the highest upregulation of PhATG4, PhATG5, $P h A T G 8 a$, and PhATG13. This ethylene treatment is not sufficient to accelerate petal senescence, but it does induce the expression of ethylene primary response genes (Chapin et al., 2017; Shibuya et al., 2013). Upregulation of PhCP10 is not detected when petunia flowers are treated with $0.1 \mu \mathrm{L} \cdot \mathrm{L}^{-1}$ ethylene (for $4 \mathrm{~h}$ ), but it is induced with $1.0 \mu \mathrm{L} \cdot \mathrm{L}^{-1}$ ethylene. $P h C P 10$ and AtSAG12 are used as genetic markers for senescence because expression is regulated directly by senescence and the response to ethylene is secondary (Chapin et al., 2017; Grbic and Bleecker, 1995; Jones et al., 2005). Our gene expression studies (Fig. 3) support a role for ethylene in mediating autophagy signaling in petunia flowers. The differences in responsiveness to ethylene suggest that some of the petunia ATGs may be primary response genes, but this would need to be confirmed with more detailed ethylene treatments. Pretreating flowers with cycloheximide, to prevent protein synthesis, could also be used to confirm that the ethylene-induced changes in gene expression occur even in the absence of de novo protein synthesis (i.e., that they are primary response genes).

Autophagy is a starvation-induced process, and the expression of $A T G$ genes is upregulated by $\mathrm{N}$ limitation (Hanaoka, 2002; Li et al., 2016; Pei et al., 2014; Rose et al., 2006). Autophagy deficient plants show accelerated starvationinduced senescence as indicated by early leaf yellowing (Doelling et al., 2002; Hanaoka, 2002). Under nutrient limited conditions, autophagy contributes to cell viability by providing nutrients from the degradation of organelles or proteins (Guiboileau et al., 2012). In autophagy deficient arabidopsis (RNAi-AtATG18a, atg9 and atg5), N remobilization efficiency is reduced under both low and high $\mathrm{N}$ conditions (Guiboileau et al., 2012). When petunia plants were grown in 
the greenhouse for 4 weeks using less than optimal fertilizer rates $\left(10 \mathrm{mg} \cdot \mathrm{L}^{-1} \mathrm{~N}\right)$, PhATG gene expression was upregulated within 2-3 weeks (Fig. 4). By contrast, wheat (Triticum aestivum) ATG genes show increased expression after $2 \mathrm{~d}$ of $\mathrm{N}$ starvation (Pei et al., 2014). To evaluate the effects of nutrient starvation, petunia plants were grown in solutions that were deficient in N, P, or K for 4 weeks. Potassium deficiency did not affect expression of the petunia $A T G$ genes (Fig. 7). Most ATG genes (PhATG4, PhATG5, PhATG6, and PhATG13) were induced slightly by $-\mathrm{P}$ and to a greater degree by $-\mathrm{N}$ stress (Fig. 7). Similarly, PhCP10 was induced only slightly by $-\mathrm{P}$, whereas the $-\mathrm{N}$ treatment resulted in a very large increase in gene expression. Interestingly, PhATG8a had the highest level of upregulation under both $-\mathrm{N}$ and $-\mathrm{P}$ conditions, but gene expression was higher in the $\mathrm{P}$ deficient plants than in the $\mathrm{N}$ deficient plants. In arabidopsis, $\mathrm{P}$ deficiency causes higher upregulation of AtATG8a, AtATG8e, and AtATG8f in the roots, whereas $\mathrm{N}$ deficiency causes higher upregulation of $A t A T G 8 i$ and AtATG8d in the shoots (Siriwat and Steffen, 2009; Yoshimoto et al., 2004). Similarly, PhATG8a may be preferentially upregulated in leaves in response to $\mathrm{P}$ deficiency rather than $\mathrm{N}$ deficiency. Thus, the autophagy machinery might be activated in petunia in response to low fertility as a survival mechanism. However, if the stress is too severe, autophagy may be accompanied by other senescence-related processes.

Autophagy is also involved in plant responses to salt stress (Liu et al., 2009; Pei et al., 2014). Under salt stress, autophagy improves cell viability by remobilizing ROS damaged proteins (Xiong et al., 2006). Autophagy deficient plants are hypersensitive to salt (Liu et al., 2009). Although the chronic salt stress treatment ( $200 \mathrm{~mm} \mathrm{NaCl}$ for up to 4 weeks) clearly had a negative impact on plant growth (Fig. 9), increases in PhATG gene expression were not detected when tissue was evaluated after 1-4 weeks (Fig. 8). Changes in gene expression were detected in young plants after only 3-24 h of exposure to $100 \mathrm{~mm} \mathrm{NaCl}$ (Fig. 10). Upregulation of $A T G$ genes after $24 \mathrm{~h}$ of salt stress $(100 \mathrm{~mm} \mathrm{NaCl})$ was also reported in foxtail millet ( $\mathrm{Li}$ et al., 2016). In wheat exposed to high salt stress $(200 \mathrm{~mm} \mathrm{NaCl})$, the expression of TaATG8a, TaATG8g, TaATG $4 a$, and TaATG4b peaks at $8 \mathrm{~h}$, then expression drops to basal levels at $12 \mathrm{~h}$ (Pei et al., 2014). In addition, changes in expression in response to salt stress $(100 \mathrm{~mm} \mathrm{NaCl})$ occur within the first $8 \mathrm{~h}$ of treatment in arabidopsis (Liu et al., 2009). Autophagic flux reaches the highest levels after $0.5 \mathrm{~h}$ of salt stress in arabidopsis (Luo et al., 2017). As was observed in the low fertility stress experiment, $P h A T G$ genes were upregulated earlier than the senescence marker PhCP10. Therefore, autophagy seems to be part of the early response to overcome salt stress; but if the salt stress is too severe it will lead to the activation of senescence-associated pathways. The early autophagic response to salt stress might be associated with the transient degradation of oxidized proteins needed to supply nutrients for quick salt-stress related protein synthesis (Kawasaki et al., 2001; Luo et al., 2017; Omidbakhshfard et al., 2012).

\section{Conclusion}

In this study, we have demonstrated that petunia $A T G$ genes are regulated during flower senescence and abiotic stress responses. Expression of PhATG genes increased concomitant with petal senescence and were induced by exogenous ethylene treatment. PhATG genes were induced by low fertility stress.
Although the role of autophagy in $\mathrm{N}$ remobilization is well documented (Guiboileau et al., 2012; Li et al., 2015), there are not many previous reports investigating $\mathrm{P}$ and $\mathrm{K}$. Phosphorus deficiency, but not $\mathrm{K}$ deficiency, induced expression of $A T G$ genes in petunia leaves. Although chronic, long-term salt stress did not result in significant increases in the expression of $A T G$ genes in leaves, acute salt stress upregulated petunia $A T G$ gene expression in seedlings within hours. In addition, the autophagy machinery was activated earlier than the senescence-associated cysteine protease $(\mathrm{PhCP} 10)$ gene, supporting the hypothesis that autophagy might work as a survival mechanism during abiotic stress. The information presented here will help us to study how autophagy contributes to flower senescence and abiotic stress tolerance. A better understanding of autophagy will help to improve longevity or stress tolerance in floriculture crops as previously observed in rice (Li et al., 2016) and arabidopsis (Xia et al., 2012). Autophagy deficient plants created via the down regulation or silencing of individual $A T G$ genes are needed to further understand the role of autophagy in flower senescence.

\section{Literature Cited}

Acosta-Motos, J.R., M.F. Ortuño, A. Bernal-Vicente, P. Diaz-vivancos, M.J. Sanchez-Blanco, and J.A. Hernandez. 2017. Plant responses to salt stress: Adaptive mechanisms. Agronomy 7:1-38.

Avila-Ospina, L., M. Moison, K. Yoshimoto, and C. MasclauxDaubresse. 2014. Autophagy, plant senescence, and nutrient recycling. J. Expt. Bot. 65:3799-3811.

Breeze, E., E. Harrison, S. McHattie, L. Hughes, R. Hickman, C. Hill, S. Kiddle, Y-S. Kim, C.A. Penfold, D. Jenkins, C. Zhang, K. Morris, C. Jenner, S. Jackson, B. Thomas, A. Tabrett, R. Legaie, J.D. Moore, D.L. Wild, S. Ott, D. Rand, J. Beynon, K. Denby, A. Mead, and V. Buchanan-Wollaston. 2011. High-resolution temporal profiling of transcripts during arabidopsis leaf senescence reveals a distinct chronology of processes and regulation. Plant Cell 23:873-894.

Broderick, S.R., S. Wijeratne, A.J. Wijeratn, L.J. Chapin, T. Meulia, and M.L. Jones. 2014. RNA-sequencing reveals early, dynamic transcriptome changes in the corollas of pollinated petunias. BMC Plant Biol. 14:1-21.

Burman, C. and N.T. Ktistakis. 2010. Regulation of autophagy by phosphatidylinositol 3-phosphate. FEBS Lett. 584:1302-1312.

Cassaniti, C., D. Romano, M.E.C.M. Hop, and T.J. Flowers. 2013. Growing floricultural crops with brackish water. Environ. Expt. Bot. 92:165-175.

Chapin, L. and M. Jones. 2007. Nutrient remobilization during pollinationinduced corolla senescence in petunia. Acta Hort. 755:181-190.

Chapin, L.J. and M.L. Jones. 2009. Ethylene regulates phosphorus remobilization and expression of a phosphate transporter (PhPT1) during petunia corolla senescence. J. Expt. Bot. 60:2179-2190.

Chapin, L.J., Y. Moon, and M.L. Jones. 2017. Downregulating a type I metacaspase in petunia accelerates flower senescence. J. Amer. Soc. Hort. Sci. 142:405-414.

Doelling, J.H., J.M. Walker, E.M. Friedman, A.R. Thompson, and R.D. Vierstra. 2002. The APG8/12-activating enzyme APG7 is required for proper nutrient recycling and senescence in Arabidopsis thaliana. J. Biol. Chem. 277:33105-33114.

Feng, Y., D. He, Z. Yao, and D.J. Klionsky. 2014. The machinery of macroautophagy. Cell Res. 24:24-41.

Fernandez-Pozo, N., N. Menda, J.D. Edwards, S. Saha, I.Y. Tecle, S.R. Strickler, A. Bombarely, T. Fisher-York, A. Pujar, H. Foerster, A. Yan, and L.A. Mueller. 2015. The sol genomics network (SGN)From genotype to phenotype to breeding. Nucleic Acids Res. 43: D1036-D1041.

Fisher, P.R., J.C. Vallejo, A.W. Hodges, and C.R. Hall. 2016. Tracking losses in floriculture crop production. Acta Hort. 1132:161-166. 
Grbic, V. and A.B. Bleecker. 1995. Ethylene regulates the timing of leaf senescence in arabidopsis. Plant J. 8:595-602.

Guiboileau, A., K. Yoshimoto, F. Soulay, M.P. Bataillé, J.C. Avice, and C. Masclaux-Daubresse. 2012. Autophagy machinery controls nitrogen remobilization at the whole-plant level under both limiting and ample nitrate conditions in arabidopsis. New Phytol. 194:732-740.

Hanaoka, H. 2002. Leaf senescence and starvation-induced chlorosis are accelerated by the disruption of an arabidopsis autophagy gene. Plant Physiol. 129:1181-1193.

Hoagland, D.R. and D.I. Arnon. 1950. The water-culture method for growing plants without soil. California Agr. Expt. Sta. Circ. 347.

Ichimura, Y., T. Kirisako, T. Takao, Y. Satomi, Y. Shimonishi, N. Ishihara, N. Mizushima, I. Tanida, E. Kominami, M. Ohsumi, T. Noda, and Y. Ohsumi. 2000. A ubiquitin-like system mediates protein lipidation. Nature 408:488-492.

Ishida, H., M. Izumi, S. Wada, and A. Makino. 2014. Roles of autophagy in chloroplast recycling. Biochim. Biophys. Acta 1837:512-521.

Jones, M.L., G.S. Chaffin, J.R. Eason, and D.G. Clark. 2005. Ethylenesensitivity regulates proteolytic activity and cysteine protease gene expression in petunia corollas. J. Expt. Bot. 56:2733-2744.

Kawasaki, S., C. Borchert, M. Deyholos, H. Wang, S. Brazille, K. Kawai, D. Galbraith, and H.J. Bohnert. 2001. Gene expression profiles during the initial phase of salt stress in rice. Plant Cell 13:889-905.

Klionsky, D.J., J.M. Cregg, W.A. Dunn, S.D. Emr, Y. Sakai, I.V. Sandoval, A. Sibirny, S. Subramani, M. Thumm, M. Veenhuis, and A. Arbor. 2003. A unified nomenclature for yeast autophagy related genes. Dev. Cell 5:539-545.

Li, F., T. Chung, J.G. Pennington, M.L. Federico, H.F. Kaeppler, S.M. Kaeppler, M.S. Otegui, and R.D. Vierstra. 2015. Autophagic recycling plays a central role in maize nitrogen remobilization. Plant Cell 27:1389-1408.

Li, W., M. Chen, E. Wang, L. Hu, M.J. Hawkesford, L. Zhong, Z. Chen, Z. Xu, L. Li, Y. Zhou, C. Guo, and Y. Ma. 2016. Genome-wide analysis of autophagy-associated genes in foxtail millet (Setaria italica L.) and characterization of the function of SiATG8a in conferring tolerance to nitrogen starvation in rice. BMC Genomics 17:1-16.

Li, Z., C.M. Baldwin, Q. Hu, H. Liu, and H. Luo. 2010. Heterologous expression of arabidopsis $\mathrm{H}+$-pyrophosphatase enhances salt tolerance in transgenic creeping bentgrass (Agrostis stolonifera L.). Plant Cell Environ. 33:272-289.

Lim, P.O., H.J. Kim, and G.N. Hong. 2007. Leaf senescence. Annu. Rev. Plant Biol. 58:115-136.

Liu, Y. and D.C. Bassham. 2012. Autophagy: Pathways for self-eating in plant cells. Annu. Rev. Plant Biol. 63:215-237.

Liu, Y., Y. Xiong, and D.C. Bassham. 2009. Autophagy is required for tolerance of drought and salt stress in plants. Autophagy 5:954-963. Luo, L., P. Zhang, R. Zhu, J. Fu, J. Su, J. Zheng, Z. Wang, D. Wang, and Q. Gong. 2017. Autophagy is rapidly induced by salt stress and is required for salt tolerance in arabidopsis. Front. Plant Sci. 8:1-13.

Machlis, L. and J.G. Torrey. 1956. Plants in action: A laboratory manual of plant physiology. Freeman, San Francisco, CA.

Maduraimuthu, D. and P.V.V. Prasad. 2013. Effects of salinity on ion transport, water relations and oxidative damage, p. 89-114. In: P. Ahmad, M.M. Azooz, and M.N.V. Prasad (eds.). Ecophysiology and responses of plants under salt stress. Springer, New York, NY.

Maillard, A., S. Diquélou, V. Billard, P. Laîné, M. Garnica, M. Prudent, J-M. Garcia-Mina, J-C. Yvin, and A. Ourry. 2015. Leaf mineral nutrient remobilization during leaf senescence and modulation by nutrient deficiency. Front. Plant Sci. 6:1-15.

Mallona, I., S. Lischewski, J. Weiss, B. Hause, and M. Egea-Cortines. 2010. Validation of reference genes for quantitative real-time PCR during leaf and flower development in Petunia hybrida. BMC Plant Biol. 10:1-11.

Miller, G., N. Suzuki, S. Ciftci-Yilmaz, and R. Mittler. 2010. Reactive oxygen species homeostasis and signalling during drought and salinity stresses. Plant Cell Environ. 33:453-467.
Omidbakhshfard, M.A., N. Omranian, F.S. Ahmadi, Z. Nikoloski, and B. Mueller-Roeber. 2012. Effect of salt stress on genes encoding translation-associated proteins in Arabidopsis thaliana. Plant Signal. Behav. 7:1095-1102.

National Center for Biotechnology Information Resource Coordinators. 2017. Database resources of the National Center for Biotechnology Information. Nucleic Acids Res. 45:D12-D17.

Pei, D., W. Zhang, H. Sun, X. Wei, J. Yue, and H. Wang. 2014. Identification of autophagy-related genes ATG4 and ATG8 from wheat (Triticum aestivum L.) and profiling of their expression patterns responding to biotic and abiotic stresses. Plant Cell Rpt. 33:1697-1710.

Rose, T.L., L. Bonneau, C. Der, D. Marty-Mazars, and F. Marty. 2006. Starvation-induced expression of autophagy-related genes in arabidopsis. Biol. Cell 98:53-67.

Shibuya, K. 2012. Molecular mechanisms of petal senescence in ornamental plants. J. Jpn. Soc. Hort. Sci. 81:140-149.

Shibuya, K., T. Niki, and K. Ichimura. 2013. Pollination induces autophagy in petunia petals via ethylene. J. Expt. Bot. 64:1111-1120.

Shin, J.H., K. Yoshimoto, Y. Ohsumi, J.S. Jeon, and G. An. 2009. OsATG10b, an autophagosome component, is needed for cell survival against oxidative stresses in rice. Mol. Cells 27:67-74.

Singh, M., J. Kumar, S. Singh, V.P. Singh, and S.M. Prasad. 2015. Roles of osmoprotectants in improving salinity and drought tolerance in plants: A review. Rev. Environ. Sci. Biotechnol. 14:407-426.

Siriwat, S. and A. Steffen. 2009. Autophagy sustains the arabidopsis root meristem during phosphate starvation. Proc. Intl. Plant Nutr. Colloq. XVI:1-5.

Suzuki, H., T. Osawa, Y. Fujioka, and N.N. Noda. 2017. Structural biology of the core autophagy machinery. Curr. Opin. Struct. Biol. 43:10-17.

van Doorn, W.G. and E.J. Woltering. 2008. Physiology and molecular biology of petal senescence. J. Expt. Bot. 59:453-480.

Vandenbussche, M., P. Chambrier, S. Rodrigues Bento, and P. Morel. 2016. Petunia your next supermodel? Front. Plant Sci. 7:1-11.

Verlinden, S. 2003. Changes in mineral nutrient concentrations in petunia corollas during development and senescence. HortScience 38:71-74.

Villarino, G.H. and N.S. Mattson. 2011. Assessing tolerance to sodium chloride salinity in fourteen floriculture species. HortTechnology 21:539-545.

Wada, S., H. Ishida, M. Izumi, K. Yoshimoto, Y. Ohsumi, T. Mae, and A. Makino. 2009. Autophagy plays a role in chloroplast degradation during senescence in individually darkened leaves. Plant Physiol. 149:885-893.

Wu, L., X. Guo, and A. Harivandi. 2017. Salt tolerance and salt accumulation of landscape plants irrigated by sprinkler and drip irrigation systems. J. Plant Nutr. 24:1473-1490.

Xia, T., D. Xiao, D. Liu, W. Chai, Q. Gong, and N.N. Wang. 2012. Heterologous expression of $A T G 8 c$ from soybean confers tolerance to nitrogen deficiency and increases yield in arabidopsis. PLoS One 7(5): $1-15$.

Xiong, Y., A.L. Contento, D.C. Bassham, C. Biology, I. Plant, and P. Program. 2005. AtATG18a is required for the formation of autophagosomes during nutrient stress and senescence in Arabidopsis thaliana. Plant J. 42:535-546.

Xiong, Y., A.L. Contento, P.Q. Nguyen, and D.C. Bassham. 2006. Degradation of oxidized proteins by autophagy during oxidative stress in arabidopsis. Plant Physiol. 143:291-299.

Yoshimoto, K. 2012. Beginning to understand autophagy, an intracellular self-degradation system in plants. Plant Cell Physiol. 53:1355-1365.

Yoshimoto, K., H. Hanaoka, S. Sato, T. Kato, S. Tabata, and T. Noda. 2004. Processing of ATG8s, ubiquitin-like proteins, and their deconjugation by ATG4s are essential for plant autophagy. Plant Cell 16:2967-2983. 